\title{
Short Communication: Immunity Gene pedB Enhances Production of Pediocin PA-1 in Naturally Resistant Lactococcus lactis Strains
}

\author{
J. L. Arqués, ${ }^{* 1}$ J. M. Rodríguez,† M. J. Gasson, ${ }^{*}$ and N. Horn* \\ ${ }^{*}$ Commensals and Microflora, BBSRC Institute of Food Research, Norwich Research Park, Colney, Norwich NR4 7UA, United Kingdom \\ †Departamento de Nutrición y Bromatología III, Facultad de Veterinaria, Universidad Complutense de Madrid, 28040 Madrid, Spain
}

\begin{abstract}
Heterologous production of the antilisterial bacteriocin pediocin PA-1 in lactococci is an attractive objective to increase the safety of dairy products. In a previous paper, we developed a system for the heterologous production of the bacteriocin pediocin PA-1 in pediocin-resistant lactococcal hosts through a leader exchange strategy. The system was based on 3 genes, 1 encoding the fusion between the lactococcin A leader and propediocin PA-1, and the other 2 encoding the lactococcin A secretion machinery. In this study, we investigated whether the addition of the pediocin PA-1 immunity gene $(p e d B)$ to this system has any effect on pediocin production. Introduction of the plasmid(s) carrying the genes described above into nisin-producing and nonnisin-producing lactococcal hosts led to a significant increase in the production of pediocin compared with the equivalent pedB-devoid systems. In addition, we obtained a nisin-producing strain with the ability to secrete pediocin PA-1 at a level equivalent to that of the parental strain Pediococcus acidilactici 347, which represents a notable improvement over our previous systems.
\end{abstract}

Key words: Lactococcus lactis, bacteriocin, immunity, heterologous production

Pediocin PA-1 is a bacteriocin with a broad inhibitory spectrum that is particularly effective against Listeria monocytogenes, a foodborne pathogen of major concern to the dairy industry (Rodríguez et al., 2002). The significant amino acid homologies shared by leader peptides and by dedicated transporters of class II bacteriocins (Havarstein et al., 1995) is the basis of an attractive approach for the heterologous production of pediocin PA-1 by lactococci (Van Belkum et al., 1997; Horn et al., 1999), which may be used as a dairy starter, adjunct, or bioprotective culture in the future. The activity of pediocin-producing lactococci obtained through such a

Received October 8, 2007.

Accepted March 5, 2008.

${ }^{1}$ Corresponding author: juan.arques@bbsrc.ac.uk strategy against L. monocytogenes, Staphylococcus aureus, and Escherichia coli O157:H7 has already been confirmed during cheese-making (Rodríguez et al., 2005)

In a previous work, pediocin PA-1 production was achieved in Lactococcus lactis using a system that was based on 3 genes: 1 (LpedA) encoding the fusion between the lactococcin A leader and propediocin PA-1, under the control of the nisin promoter $\left(\mathrm{P}_{n i s A}\right)$ and the other 2 (lcnCD) encoding the lactococcin A secretion machinery, under the control of their own common promoter (Horn et al., 2004). Because the lactococcal hosts were naturally resistant to pediocin PA-1, the gene conferring immunity to this bacteriocin (pedB) was not included in the system.

However, resistance and immunity to a bacteriocin are not equivalent properties. Bacteriocin producers are protected from their own bacteriocin by the concomitant expression of a cognate immunity protein (Fimland et al., 2002). Their cotranscription can play a crucial role for the bacteria to be able to produce and withstand the bacteriocin (Quadri et al., 1997; Eijsink et al., 1998; Kemperman et al., 2003). In this context, the aim of this study was to assess if the introduction of pedB, the pediocin PA-1 immunity gene in the heterologous system previously developed, may lead to an enhancement of pediocin PA-1 production in Lactococcus lactis.

Lactococcal strains used in this study are listed in Table 1 and were grown as described previously (Horn et al., 2004). Pediococcus acidilactici 347 (Rodríguez et al., 1997) was grown in de Man, Rogosa, and Sharpe (MRS) medium at $30^{\circ} \mathrm{C}$. Escherichia coli was used as an initial cloning host and was grown in Luria broth at $37^{\circ} \mathrm{C}$ on an orbital shaker. When appropriate, chloramphenicol (Sigma, Poole, UK) or erythromycin (Sigma) was added to the cultures (Horn et al., 2004).

Initially, the splice overlap extension technique was used to construct a fragment containing $2 \mathrm{P}_{n i s}$-controlled genes: the hybrid structural gene (LpedA) and pedB. This involved the amplification of 2 DNA fragments. Primers pAD1 (5'-CCTGAATAATATAGAGATAGGTT-3') (Horn et al., 2004) and plcnF (5'-CCATTACCGTAGTATTTTCCTCCGTTAGCTTC-3') (Horn et al., 1998) were used to amplify a 330-bp fragment (fragment 
Table 1. Lactococcal strains used in this study

\begin{tabular}{|c|c|c|c|c|c|c|c|c|}
\hline \multirow[b]{2}{*}{ Strain no. } & \multirow[b]{2}{*}{ Host } & \multirow[b]{2}{*}{ Plasmid } & \multicolumn{5}{|c|}{ Bacteriocin determinant ${ }^{1}$} & \multirow[b]{2}{*}{ Reference or source } \\
\hline & & & $n L p e d A$ & $n L p e d A B$ & $\operatorname{lcn} C D$ & nis & $\Delta$ nis & \\
\hline & FI7847 & & & & & & + & Dodd et al., 1996 \\
\hline & FI5876 & & & & & + & & Dodd et al., 1990 \\
\hline FI9917 & FI7847 & $\begin{array}{l}\text { pFI2391 } \\
\text { pFI2148 }\end{array}$ & + & & + & & + & Horn et al., 2004 \\
\hline FI10411 & FI7847 & $\begin{array}{l}\text { pFI2518 } \\
\text { pFI2148 }\end{array}$ & & + & + & & + & This study \\
\hline FI10389 & FI7847 & pFI2512 & + & & + & & + & This study \\
\hline FI10488 & FI7847 & pFI2527 & & + & + & & + & This study \\
\hline FI10038 & FI5876 & $\begin{array}{l}\text { pFI2391 } \\
\text { pFI2148 }\end{array}$ & + & & + & + & & Horn et al., 2004 \\
\hline FI10415 & FI5876 & $\begin{array}{l}\text { pFI2518 } \\
\text { pFI2148 }\end{array}$ & & + & + & + & & This study \\
\hline FI10392 & FI5876 & pFI2512 & + & & + & + & & This study \\
\hline FI10486 & FI5876 & pFI2527 & & + & + & + & & This study \\
\hline
\end{tabular}

${ }^{1} n L p e d A$ contains the hybrid $L$-pedA gene preceded by the nisin promoter; $n L p e d A B$ contains the hybrid $L$-ped $A B$ gene preceded by the nisin promoter; nis contains the nisin gene cluster; and $\Delta$ nis contains the nisin gene cluster with a frameshift mutation in codon 16 of the nisin structural gene impeding nisin biosynthesis (the sequences of the downstream nisin cluster genes are unaffected).

1) containing $\mathrm{P}_{n i s A}$ and the part of the hybrid gene encoding the lactococcin A leader. Plasmid pFI2391 (Horn et al., 2004) was used as template. The 17 nucleotides forming a tail at the $5^{\prime}$ end of primer plenF (underlined) are complementary to the sequence encoding the aminoterminal portion of mature pediocin PA-1. Primers ppedE (5'-GAAGCTAACGGAGGAAAATACTACGGTAATGG-3') (Horn et al., 1998) and ppedG (5'-TTCTTAGACAACTACAATATCCC-3') were employed to amplify a 560-bp fragment (fragment 2), comprising the part of the hybrid gene encoding mature pediocin PA-1 and pedB using $P$. acidilactici 347 as the template. Primer ppedE was designed with a $5^{\prime}$ tail of 15 nucleotides (underlined) that were complementary to a part of the sequence encoding the lactococcin A leader. Fragments 1 and 2 were diluted in water and mixed in equal quantities; the mixture was then used as template to amplify an 835-bp fragment with primers pAD1 and ppedG. This fragment was cloned into pCR2.1 (Invitrogen, Paisley, UK), and nucleotide sequence analysis confirmed that it was composed of sequences corresponding precisely to the construction LpedA-pedB under the control of $P_{n i s A}$. The hybrid genes and upstream promoter region were isolated as an EcoRI fragment and cloned into pTG262 to generate pFI2518. Cotransformation of L. lactis FI7847 and FI5876 with pFI2518 and pFI2148 (a plasmid that carries the lcnCD genes; Horn et al., 1999) generated strains FI10411 and FI10415, respectively. In addition, a 3.8-kb $S a c \mathrm{I} / \mathrm{X} b a \mathrm{I}$ fragment from $\mathrm{pFI} 2148$ containing the $l c n C D$ genes and the upstream promoter was cloned into pFI2391 ( $\mathrm{P}_{\text {nisA }}$-LpedA) (Horn et al., 2004) and pFI2518 $\left(\mathrm{P}_{\text {nisA }}\right.$-LpedA-pedB) to generate pFI2512 and pFI2527, respectively. Transformation of $L$. lactis FI7847 with pFI2512 or pFI2527 generated FI10389 and
FI10488, respectively, and transformation of L. lactis FI5876 generated FI10392 and FI10486, respectively.

Plate diffusion bioassays (Dodd et al., 1992) were performed in triplicate to detect pediocin PA-1 and nisin antimicrobial activities in culture supernatants of $L$. lactis FI7847, FI5876, and their respective transformants. All the cultures had a bacterial concentration of approximately $1 \times 10^{9} \mathrm{cfu} / \mathrm{mL}$. Such activities were also evaluated using a microtiter plate assay as described by Holo et al. (1991). Enterococcus faecalis TAB 28 (pediocin-sensitive, nisin-resistant; Joosten et al., 1997) and L. lactis FI9180 (pediocin-resistant, nisin-sensitive; Horn et al., 2004) were used as the indicator organisms. A series of pediocin PA-1 standards in GM17 broth, ranging from 0 to $5 \mu \mathrm{g} / \mathrm{mL}$, was used to quantify the production of this bacteriocin. Pediocin PA-1 purity was determined by a competitive indirect ELISA using the polyclonal antibodies and the conditions described by Martínez et al. (1999).

All the L. lactis recombinant strains were able to produce pediocin PA-1 provided that, in the case of the FI7847 derivatives, subinhibitory levels of nisin A (100 $\mathrm{ng} / \mathrm{mL}$ ) were added to the culture media. The agar bioassays revealed that, among the FI7847 derivatives, the pediocin yields of FI9917, FI10411, FI10389, and FI10488 were $288,514,648$, and $835 \mathrm{ng} / \mathrm{mL}$, respectively (Table 2). These yields represent between 17 and $49 \%$ of the pediocin found in the culture supernatants of $P$. acidilactici 347 . These results showed that introduction of the pedB gene in the heterologous production system increased pediocin PA-1 production when all the genes required for its biosynthesis were distributed either in 2 plasmids (FI9917 vs. FI10411; increase of $13 \%$ with respect to the parental strain) or in an unique plasmid 
Table 2. Pediocin PA-1 production ${ }^{1}$

\begin{tabular}{lrrrrr}
\hline & \multicolumn{2}{c}{ Plate diffusion method } & & \multicolumn{2}{c}{ Microplate method } \\
\cline { 2 - 3 } Strain & $\mathrm{ng} / \mathrm{mL} \pm \mathrm{SD}$ & $\%$ & & \multicolumn{1}{c}{$\mathrm{BU}^{2} \pm \mathrm{SD}$} & $\%$ \\
\hline Pediococcus acidilactici 347 & $1,698 \pm 25$ & 100 & & $1,280 \pm 40$ & 100 \\
Lactoccus lactis FI9917 & $288 \pm 11$ & 17 & & $232 \pm 16$ & 18 \\
L. lactis F10411 & $514 \pm 13$ & 30 & & $412 \pm 24$ & 33 \\
L. lactis FI10389 & $648 \pm 16$ & 38 & & $528 \pm 32$ & 42 \\
L. lactis FI10488 & $835 \pm 22$ & 49 & & $695 \pm 38$ & 55 \\
L. lactis FI10038 & $638 \pm 16$ & 38 & & $424 \pm 28$ & 34 \\
L. lactis FI10415 & $624 \pm 21$ & 37 & & $490 \pm 29$ & 39 \\
L. lactis FI10392 & $1,215 \pm 34$ & 72 & & $873 \pm 49$ & 69 \\
L. lactis FI10486 & $1,657 \pm 47$ & 98 & & $1,208 \pm 53$ & 96 \\
\hline
\end{tabular}

${ }^{1}$ Values are given for bacteriocin concentration/activity and percentage of the yield achieved by the natural producing strain, Pediococcus acidilactici 347.

${ }^{2} \mathrm{One} \mathrm{BU}$ (bacteriocin unit) is defined as the reciprocal of the highest dilution causing $50 \%$ growth inhibition of the indicator organism Enterococcus faecalis TAB 28.

(FI10389 vs. FI10488; increase of 11\%). In addition, pediocin production was greater using the single-plasmid system (Table 2). The reason for this increased yield was that, in this case, all the genes required for heterologous production of pediocin PA-1 are carried on a lactococcal plasmid (pFI2512 or pFI2527) derived from pSH71, which is maintained at 50 to 60 copies per cell (Gasson and Anderson, 1985). In contrast, in the 2-plasmid system, $l c n C$ and $l c n D$ are carried by the low-copy-number plasmid pFI2148 (6 to 9 copies per cell; Simon and Chopin, 1988), a fact that may affect the efficiency of pediocin PA-1 secretion.

In relation to the FI5876 derivatives, the bioassays showed that the pediocin yields of FI10038, FI10415, FI10392, and FI10486 were 638, 624, 1,215, and 1,657 $\mathrm{ng} / \mathrm{mL}$, respectively (Table 2 ). The strains carrying the 2-plasmid system (FI10038, FI10415) produced a similar amount of pediocin PA-1 (624 to $638 \mathrm{ng} / \mathrm{mL}$ ), regardless of the presence or not of pedB. Probably, this observation is due to the saturation of the dedicated secretion process once a pediocin concentration of $600 \mathrm{ng} / \mathrm{mL}$ is achieved and, again, reflects the limitation of carrying $\operatorname{lcn} C D$ genes in a low-copy plasmid. In fact, when the $\operatorname{lcn} C D$ genes were included in the single high-copy plasmid system (strains FI10392 and FI10486), pediocin production increased significantly $(>34 \%)$ and this enhancement was notably greater $(60 \%)$ when pedB was included (FI10486). As a result, the pediocin concentration found in the supernatants of FI10486 was similar (98\%) to that found in $P$. acidilactici 347 supernatants.

The fact that the pediocin PA-1 yields of the FI5876 derivatives were greater than those of their FI7847-derived equivalents may reflect the amount of inducing nisin present in the external environment. The nisinproducing FI5876 cells are in a permanent state of induction with continual production of the lantibiotic (Dodd et al., 1996), whereas nisin-controlled pediocin PA-1 pro- duction by FI7847 derivatives relied on subinhibitory levels of nisin added to the growth medium. Lactococcus lactis FI7847 is an FI5876 derivative that carries a 20bp insertion in the nisin structural gene nisA, resulting in its inactivation; however, the nisin promoter of FI7847 is unaffected, allowing expression of downstream genes as a result of transcriptional readthrough (Dodd et al., 1996).

Agar diffusion and microtiter plate bioassays showed good correlation when the values were expressed as a percentage of the yield or activity achieved by $P$. acidilactici 347 supernatants (Table 2). In addition, both techniques revealed that all FI5876 derivatives produced quantities of nisin at 92 to $98 \%$ of that of the parental strain FI5876, which is in agreement with previously published data by Horn et al. (1999, 2004). Lactococcus lactis FI10486 has the ability to coproduce 2 wide-spectrum bacteriocins, pediocin PA-1 and nisin A, at levels comparable to the respective parental strains. Previous studies have reported maximum pediocin yields of approximately $30 \%$ of that of $P$. acidilactici 347 in laboratory (Horn et al., 2004) or wild (Reviriego et al., 2005, 2007) lactococcal strains that coproduce nisin and pediocin PA-1 through the leader exchange strategy. The synergistic effects of these 2 unrelated bacteriocins against foodborne pathogens and the beneficial effects of their coproduction (Hanlin et al., 1993; Mulet-Powell et al., 1998; Horn et al., 2004) can be exploited to extend their potential application in the dairy industry.

In this study, introduction of pedB led to an increase in pediocin yields when the secretion process was not constrained by a low $l c n C D$ copy number. Therefore, cotranscription of the structural and immunity genes may have a positive effect on heterologous systems for bacteriocin production, even in those hosts that are naturally resistant to the antimicrobial peptide. Growth curves produced similar characteristics for L. lactis 
strains with and without the pedB gene. Also, the increase in pediocin PA-1 yields was shown not to be accompanied by an increase in the bacterial resistance to this bacteriocin because all were naturally resistant to pediocin at the maximum concentration tested (approximately $2 \mu \mathrm{g} / \mathrm{mL}$ ) during plate diffusion bioassays. Serial subcultures of L. lactis FI10486 showed stability of pFI2527 in the lactococcal host for at least 100 generations under nonselective conditions. Presence of PedB may increase the efficacy of the biosynthetic process because it has been described that one of the nisin immunity systems (NisFEG) is a membrane-protein complex that contributes to the transport of the lantibiotic from the cytoplasmic membrane to the extracellular space (Stein et al., 2003). A role for other bacteriocin immunity genes in the export of antimicrobial agents has also been reported (Matsumoto-Nakano and Kuramitsu, 2006). Work is in progress to investigate the efficacy of this pediocin-production system in wild L. lactis strains when they are added as adjunct cultures for the control of undesirable microorganisms during cheese ripening.

\section{ACKNOWLEDGMENTS}

This work was partially supported by grant AGL200204609-C02-02 from the Comisión Interministerial de Ciencia y Tecnología (CICYT, Madrid, Spain). J.A. holds a fellowship from Ministerio de Educación y Ciencia, Spain.

\section{REFERENCES}

Dodd, H. M., N. Horn, W. C. Chan, C. J. Giffard, B. W. Bycroft, G. C. K. Roberts, and M. J. Gasson. 1996. Molecular analysis of the regulation of nisin immunity. Microbiology 142:2385-2392.

Dodd, H. M., N. Horn, and M. J. Gasson. 1990. Analysis of the genetic determinant for production of the peptide antibiotic nisin. J. Gen. Microbiol. 136:555-566.

Dodd, H. M., N. Horn, H. Zhang, and M. J. Gasson. 1992. A lactococcal expression system for engineered nisins. Appl. Environ. Microbiol. 58:3683-3693.

Eijsink, V. G. H., M. Skeie, H. Middelhoven, M. B. Brurberg, and I. F. Nes. 1998. Comparative studies of pediocin-like bacteriocins. Appl. Environ. Microbiol. 64:3275-3281.

Fimland, G., V. G. H. Eijsink, and J. Nissen-Meyer. 2002. Comparative studies of immunity proteins of pediocin-like bacteriocins. Microbiology 148:3661-3670.

Gasson, M. J., and P. H. Anderson. 1985. High copy number plasmid vectors for use in lactic streptococci. FEMS Microbiol. Lett. 30:193-196.

Hanlin, M. B., N. Kalchayanand, P. Ray, and B. Ray. 1993. Bacteriocins of lactic acid bacteria in combination have greater antibacterial activity. J. Food Prot. 56:252-255.

Havarstein, L. S., D. B. Diep, and I. F. Nes. 1995. A family of bacteriocin $\mathrm{ABC}$ transporters carry out proteolytic processing of their substrates concomitant with export. Mol. Microbiol. 16:229-240.

Holo, H., O. Nilssen, and I. F. Nes. 1991. Lactococcin A, a new bacteriocin from Lactococcus lactis subsp. cremoris: Isolation and characterization of the protein and its gene. J. Bacteriol. 173:3879-3887.
Horn, N., A. Fernández, H. M. Dodd, M. J. Gasson, and J. M. Rodríguez. 2004. Nisin-controlled production of pediocin PA-1 and colicin V in nisin- and non-nisin-producing Lactococcus lactis strains. Appl. Environ. Microbiol. 70:5030-5032.

Horn, N., M. I. Martínez, J. M. Martínez, P. E. Hernández, M. J. Gasson, J. M. Rodríguez, and H. M. Dodd. 1998. Production of pediocin PA-1 by Lactococcus lactis using the lactococcin A secretory apparatus. Appl. Environ. Microbiol. 64:818-823.

Horn, N., M. I. Martínez, J. M. Martínez, P. E. Hernández, M. J. Gasson, J. M. Rodríguez, and H. M. Dodd. 1999. Enhanced production of pediocin PA-1 and coproduction of nisin and pediocin PA1 by Lactococcus lactis. Appl. Environ. Microbiol. 65:4443-4450.

Joosten, H. M. L. J., E. Rodríguez, and M. Núñez. 1997. PCR detection of sequences similar to the AS- 48 structural gene in bacteriocinproducing enterococci. Lett. Appl. Microbiol. 24:40-42.

Kemperman, R., M. Jonker, A. Nauta, O. P. Kuipers, and J. Kok. 2003. Functional analysis of the gene cluster involved in production of the bacteriocin circularin A by Clostridium beijerinckii ATCC 25752. Appl. Environ. Microbiol. 69:5839-5848.

Martínez, J. M., M. I. Martínez, A. M. Suárez, C. Herranz, P. Casaus, L. Cintas, J. M. Rodríguez, and P. E. Hernández. 1999. Antibodies to a synthetic 1-9-N-terminal amino acid fragment of mature pediocin PA-1: Sensitivity and specificity for pediocin PA-1 and crossreactivity against Class IIa bacteriocins. Microbiology 145:27772787.

Matsumoto-Nakano, M., and H. K. Kuramitsu. 2006. Role of bacteriocin immunity proteins in the antimicrobial sensitivity of Streptococcus mutans. J. Bacteriol. 188:8095-8102.

Mulet-Powell, N., A. M. Lacoste-Armynot, M. Viñas, and M. S. de Buochberg. 1998. Interactions between pairs of bacteriocins from lactic acid bacteria. J. Food Prot. 61:1210-1212.

Quadri, L. E. N., M. Kleerebezem, O. P. Kuipers, W. M. de Vos, K. L. Roy, J. C. Vederas, and M. E. Stiles. 1997. Characterization of a locus from Carnobacterium piscicola LV17B involved in bacteriocin production and immunity: Evidence for global inducer-mediated transcription regulation. J. Bacteriol. 179:6163-6171.

Reviriego, C., A. Fernández, N. Horn, E. Rodríguez, M. L. Marín, L. Fernández, and J. M. Rodríguez. 2005. Production of pediocin PA-1, and coproduction of nisin A and pediocin PA-1, by wild Lactococcus lactis strains of dairy origin. Int. Dairy J. 15:45-49.

Reviriego, C., L. Fernández, O. P. Kuipers, J. Kok, and J. M. Rodriguez. 2007. Enhanced production of pediocin PA-1 in wild nisin- and non-nisin-producing Lactococcus lactis strains of dairy origin. Int. Dairy J. 17:574-577.

Rodríguez, E., J. Calzada, J. L. Arqués, J. M. Rodríguez, M. Nuñez, and M. Medina. 2005. Antimicrobial activity of pediocin-producing Lactococcus lactis on Listeria monocytogenes, Staphylococcus aureus and Escherichia coli O157:H7 in cheese. Int. Dairy J. 15:51-57.

Rodríguez, J. M., L. M. Cintas, P. Casaus, M. I. Martínez, A. Suárez, and P. E. Hernández. 1997. Detection of pediocin PA-1-producing pediococci by rapid molecular biology techniques. Food Microbiol. 14:363-371.

Rodríguez, J. M., M. I. Martínez, and J. Kok. 2002. Pediocin PA-1, a wide-spectrum bacteriocin from lactic acid bacteria. Crit. Rev. Food Sci. Tech. 42:91-121.

Simon, D., and A. Chopin. 1988. Construction of a vector plasmid family and its use for molecular cloning in Streptococcus lactis. Biochimie 70:559-566.

Stein, T., S. Heinzmann, I. Solovieva, and K. D. Etian. 2003. Function of Lactococcus lactis nisin immunity genes nisI and nisFEG after coordinated expression in the surrogate host Bacillus subtilis. J. Biol. Chem. 278:89-94.

Van Belkum, M. J., R. W. Worobo, and M. E. Stiles. 1997. Doubleglycine-type leader peptides direct secretion of bacteriocins by $\mathrm{ABC}$ transporters: Colicin V secretion in Lactococcus lactis. Mol. Microbiol. 23:1293-1301. 